\title{
ニンヒドリンによる混合製凨中のアミノプロピロン 比色定量法の検討*
}

\author{
小泉 淳二，世一 義隆，竹本 禎三郎**
}

\begin{abstract}
アミノプロピロンの比色定量法について検討した.
アミノプロピロンを鉱酸で加熱分解したものは, 弱酸性下, 室温に打いて容易に紫紅色 $\left(\lambda_{\max }=414\right.$ ～ $416 \mathrm{~m} \mu, 536 \mathrm{~m} \mu)$ を呈する特異的なニンヒドリン反応を見いだした．との発色反応はアミノプロピロ ン濃度 4 $28 \mu \mathrm{g} / \mathrm{ml}$ の範囲内で，ベールの法則を満足し定量に利用しうることを知った。本法はきわ めて精度のよい比色定量法である $\left(\sigma^{\prime}=0.272 \%\right)$.

鎮痛薬，感冒薬としてしぱしば配合される塩酸エフェドリン，スルピリン，硫酸キニーネ，塩酸ノス カピンなどの塩基性物質が共存する製剤に预いては，従来使われている滴定法でアミノプロピロンを定 量することは困難であるが，本法ではこれら成分の影響なく簡単に定量することができた。
\end{abstract}

\section{1 緒 言}

アミノプロピロンの定量は，従来その塩基性を利用し た中和滴定法（非水滴定法を含む）が使用されてきた が，製鄅中に配合された本品の定量にあたり，共存塩基 性物質の障害除去に煩雑な前処理它必要とする場合が多 い.今回，われわれはアミノプロピロンの酸分解物が弱 酸性において，ニンヒドリンにより紫紅色に発色する反 応を見いだし，これを応用した比色定量法について検討 し簡単な比色定量法を確立するとともに, 配合医薬品の 影響について検討した。

\section{2 試料, 試薬および測定機器}

アミノプロピロン（融点: $\left.186^{\circ} \mathrm{C}\right) ， 20(\mathrm{v} / \mathrm{v}) \%$ 打よ び $35(\mathrm{v} / \mathrm{v}) \%$ 硫酸, $30(\mathrm{w} / \mathrm{v}) \%$ 托よび $5(\mathrm{w} / \mathrm{v}) \%$ 水酸化ナトリウム溶液, McIlvaine（pH 2.2〜 8.0) 拉 よび Kolthoff ( $\mathrm{pH}$ 9.2〜 10.0) の緩衝液，酢酸塩緩 重液 $\mathrm{pH} 4.3$ (日本薬局方試液)，1.0 (w/v) \% ニンヒ ドリン溶液, その他試薬類はすべて特級品を使用した。 なお，機器類は東亜電波社製 $\mathrm{HM}-5 \mathrm{~A}$ 型 $\mathrm{pH}$ メー夕 一, 日立自記分光光度計EPS- 2 , ベックマン分光光度計 DU 型, 層長 $10 \mathrm{~mm}$ の石英セルを使用した。

\section{3 定 量 法}

デシケーター（硫酸）で 3 時間乾燥したアミノプロピ ロン約 $80 \mathrm{mg}$ を精密に量り，35(v/v) \% 硫酸 $10 \mathrm{ml}$

*アミノプロピロンの分析研究（第 1 報）

** 日本新薬株式会社開発試験部分析課 : 京都市南区西 大路八条下ル
を加光, 還流冷却器を付して 直火で 3 時間加熱したの ち, 水で適当に希䣋し, じゅうぶんに氷冷しつつ $30(\mathrm{w} /$ v）\%水酸化ナトリウム溶液, ついで $5(\mathrm{w} / \mathrm{v}) \%$ 水酸 化ナトリウム溶液を加え, $\mathrm{pH}$ を約 4 に $\mathrm{pH}$ メーターを 用いて調整, 水を加えて正確に $200 \mathrm{ml}$ とする. この液

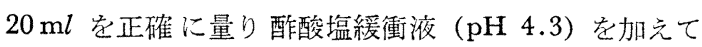
正確に $100 \mathrm{~m} l$ とし試料溶液とする. 別にデシケーター (硫酸) で 3 時間乾燥したアミノプロピロン標準品約 80 mg を精密に量り，同様操作して調製した溶液を標準溶 液とする。標準溶液（ $\mathrm{S}$ ), 試料溶液（T) および 水 (から試験) $5 \mathrm{~m} l$ をそれぞれ $25 \mathrm{ml}$ のメスフラスコに正 確に量り, 酢酸塩緩衝液 ( $\mathrm{pH} 4.3) 10 \mathrm{ml}$ を加え, つ いで $1.0(\mathrm{w} / \mathrm{v}) \%$ ニンヒドリン溶液 $5 \mathrm{ml}$ を正確に加 え, さらに酰酸塩緩衝液 ( $\mathrm{pH}$ 4.3) を加光て正確に 25 $\mathrm{m} l$ とする. 室温 $\left(20 \sim 30^{\circ} \mathrm{C}\right)$ に 20 分間放置したのち, から試験液を対照とし，層長 $10 \mathrm{~mm}$ で波長 $536 \mathrm{~m} \mu$ の 吸光度 $E_{\mathrm{S}}$ および $E_{\mathrm{T}}$ を測定する。

$$
\begin{aligned}
& \text { アミノプロピロン }\left(\mathrm{C}_{16} \mathrm{H}_{22} \mathrm{O}_{2} \mathrm{~N}_{4}\right) \text { の量 }(\mathrm{mg}) \\
& \text { =アミノプロピロン標準品の量 }(\mathrm{mg}) \times \frac{E_{\mathrm{T}}}{E_{\mathrm{S}}}
\end{aligned}
$$

\section{4 定量条件の検討}

\section{1 吸収曲線}

3 に準じて得たアミノプロピロン酸分解液の弱酸性に おけるニンヒドリンとの反応発色液は，から試験液を対 照として測定するとき，波長 414〜416 m $\mu$ および 536 $\mathrm{m} \mu$ に吸収極大を示す（Fig. 1).

から試験液は, 水を対照として測定するとき,波長 536 


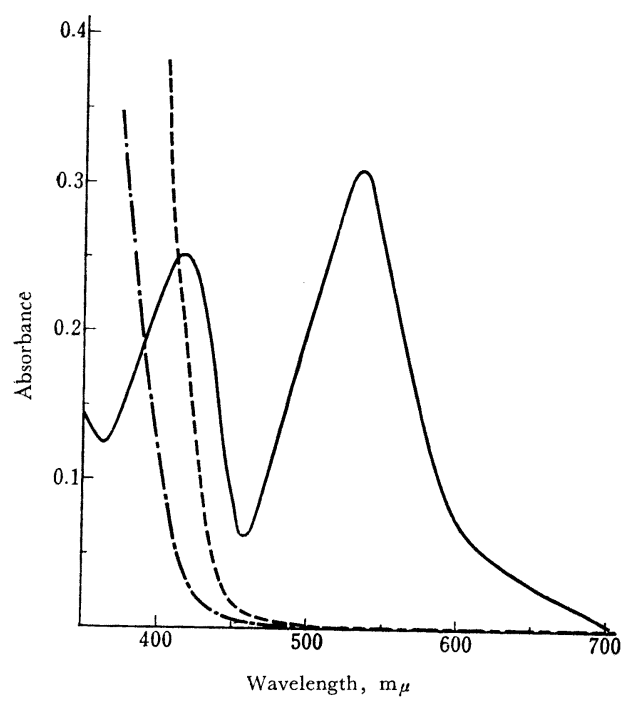

Fig. 1 Absorption spectra

- Colored solution of the hydrolized matter of aminopropylon with ninhydrin. Reference : Reagent blank

-.-.- $1 \%$ Ninhydrin solution. Reference: Water

--_ Reagent blank. Reference: Water

$\mathrm{m} \mu$ に吸収を示さないので，波長 $536 \mathrm{~m} \mu$ を定量に使用 することにした。

\section{2 発色反応における pH の影響}

本発色反忘情弱性下, 室温において容易に進行する が，ニンヒドリン反応は一般に加熱するとき促進され る122). したがって, 室温における至適 $\mathrm{pH}$ を追究する とともに加熱したときの発色状態についてもあわせて検 討した。すなわち，3に準じて分解，中和した液を 200 $\mathrm{m} l$ (アミノプロピロン濃度 : $400 \mu \mathrm{g} / \mathrm{ml}$ ) とし, その $1 \mathrm{ml}$ に各 $\mathrm{pH}$ の McIlvaine および Kolthoff の緩衝液 $10 \mathrm{ml}$ を加え, ついで $1.0(\mathrm{w} / \mathrm{v}) \%$ ニンヒドリン溶液 $.5 \mathrm{ml}$ を加え, さらに各緩衝液を加えて $25 \mathrm{ml}$ としたの ち，この液を二分し，一方は室温 (約 $25^{\circ} \mathrm{C}$ ) に 40 分 間放置，他方浽約 $90^{\circ} \mathrm{C}$ に 10 分間加熱後流水下 (約 $20^{\circ} \mathrm{G}$ ) に5 分間泠却し, 室温 (約 $25^{\circ} \mathrm{C}$ ) に 25 分間放 置したのち吸光度を測定した. その結果，発色 40 分後 における吸光度は, 加熱しないもの，加熱したものとも に $\mathrm{pH} 5$ で最高值を示したが，加熱したものの $\mathrm{pH} 5$ での吸光度は加熱しないものに比べて低值を得, $\mathrm{pH} 6$, pH 7, pH 8 においていくぶえ高值を得た (Fig. 2-a). このことは各 $\mathrm{pH}$ に打ける発色反応の反応速度が加熱し た場合と室温での場合とそれぞれ異なり，発色反応の促 進と発色物の次の变化 (分解) の進行速度の差を示すも

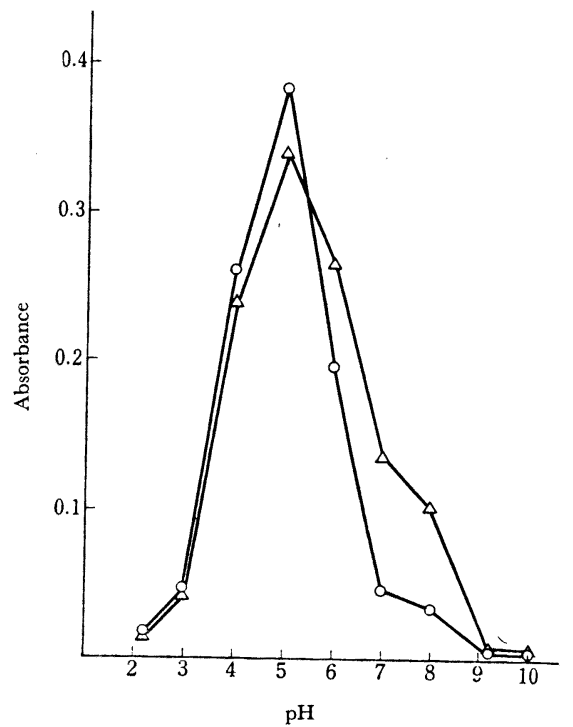

Fig. 2-a Effect of $\mathrm{pH}$

Absorbance at wavelength $536 \mathrm{~m} \mu$ of colored solution after $40 \mathrm{~min}$.

Stand under room temperature $\left(25^{\circ} \mathrm{C}\right)$ for $40 \mathrm{~min}$.

$\triangle$ Heat $10 \mathrm{~min}$ at $90^{\circ} \mathrm{C}$, cool $5 \mathrm{~min}$ at $20^{\circ} \mathrm{C}$ and stand under room temperature $\left(25^{\circ} \mathrm{C}\right)$ for $25 \mathrm{~min}$.

のと考えられる・

また，室温における各 $\mathrm{pH}$ での発色反応の反応状態を 検討するため, 同じアミノプロピロン酸分解液（アミ， プロピロン濃度 : $400 \mu \mathrm{g} / \mathrm{ml}) 1 \mathrm{ml}$ に $\mathrm{pH} 4.0 \sim 6.0$ の McIlvaine の緩衝液 $10 \mathrm{ml}$ を加え, ついで $1.0(\mathrm{w} / \mathrm{v})$ $\%$ ニレドリン溶液 $5 \mathrm{ml}$ を加え, さらに緩衝液を加え $\tau 25 \mathrm{ml}$ とした溶液につき, 15 分間隔で吸光度を測定し た結果, $\mathrm{pH} 4.0$ 〜 6.0 の範囲における 発色液の 経時変 化は，pH 值が低下するにつれて発色は与みやかに安定 するが，反対に $\mathrm{pH}$ 值が大きくなるにつれて安定する玄 でに時間を要し，徐々に吸光度を増加し長時間後ではす しろ $\mathrm{pH}$ 值の低い場合より大きな吸光度を示すようにな る.これら発色液の吸収極大波長 $(536 \mathrm{~m} \mu)$ は $\mathrm{pH}$ の 変動によって変化しない. $\mathrm{pH} 4.0$ 4.4 の範囲内では発 色 15 分後で完全に安定し, 定量を短時間で行なうため には，この $\mathrm{pH}$ 4.0〜 4.4 の範囲它使用するのがよい ことがわかった（室温：約 $25^{\circ} \mathrm{C}$ ) (Fig.2-b).

われわれは酶酸塩緩衝液（pH 4.3）においてもMcIlvaine の緩衝液と同様に発色しすみやかに安定するこ と苍知ったが，この緩衝液は調製が簡単であり緩衝能己 すぐれているため（水で 2 倍に希勫しても $\mathrm{pH}$ の変動は みられず, 4 倍に希釈するとき $0.1 \mathrm{pH}$ 值は增加する)， 発色の安定が速いこと，発色に加熱を要しない長所をと 


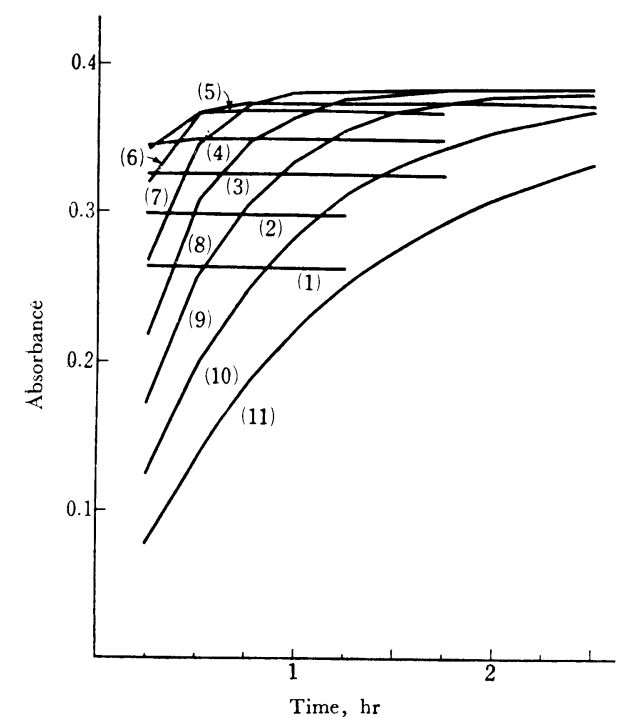

Fig. 2-b Effect of standing time on the absorbance at different $\mathrm{pH}$

$\mathrm{pH}-(1) 4.0$, (2) 4.2 , (3) 4.4 , (4) 4.6 , (5) 4.8 , (6) 5.0 , (7) 5.2 , (8) 5.4 , (9) 5.6 , (10) 5.8 , (11) 6.0 Wavelength : $536 \mathrm{~m}_{\mu}$

わ，これを定量法に使用することにした。

\section{3 発色液の温度による影響}

3 に準じ, ニンヒドリンによる発色を温度 $5 \sim 35^{\circ} \mathrm{C}$ の範囲で行ない吸光度を測定した結果, 本発色反応山 $\mathrm{pH} 4.3$ に打いて若干温度の影響を受けるが, 反応温度 $20 \sim 30^{\circ} \mathrm{C}$ の範囲では発色後 15 分間で発色液は安定し, 40 分後においても変化しないことを知った（Fig. 3). したがって，定量法では室温 $\left(20 \sim 30^{\circ} \mathrm{C}\right)$ で 20 分間放 置後吸光度を測定することにした。

\section{4 加水分解条件}

アミノプロピロン $80 \mathrm{mg}$ に $20(\mathrm{v} / \mathrm{v}) \%$ 硫酸打よび $35(\mathrm{v} / \mathrm{v}) \%$ 硫酸 $10 \mathrm{~m} l$ を加え, それぞれ $1 ， 2 ， 3 ， 4 ， 5$ 時間加熱還流，冷後中和した液を $200 \mathrm{ml}$ (アミノプロ ピロン濃度 : $400 \mu \mathrm{g} / \mathrm{m} l)$ とし，その $1 \mathrm{~m} l$ に酶酸塩緩 衝液（pH 4.3） $10 \mathrm{ml}$ を加え，ついで $1.0(\mathrm{w} / \mathrm{v}) \%$ ニンヒドリン溶夜 $5 \mathrm{ml}$ を加え, さらに酶酸塭綏衝液

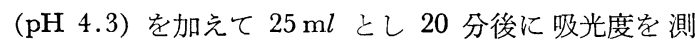
定した (Fig. 4).アミノプロピロンの加水分解に执い て，20(v/v)％硫酸を加えて行なうとき 5 時間加熱し てもなお一定した吸光度を示さないが, 35 (v/v) \% 硫 酸を加えて行なうとき約 3 時間で一定した吸光度を示し

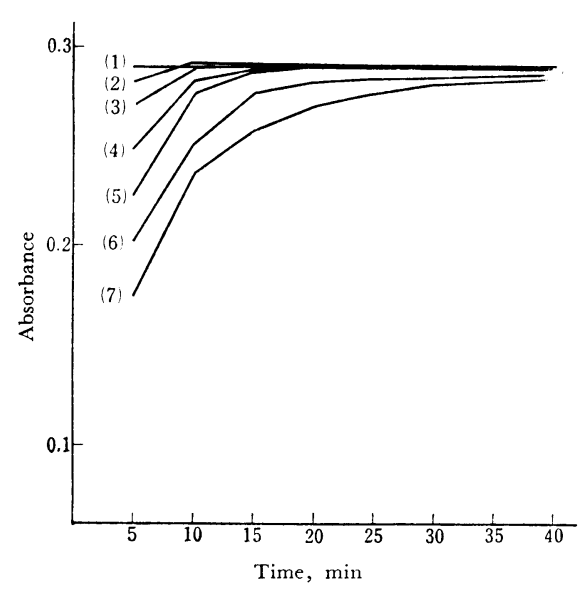

Fig. 3 Effect of reaction temperature

(1) $35^{\circ} \mathrm{C}$, (2) $30^{\circ} \mathrm{C}$, (3) $25^{\circ} \mathrm{C}$, (4) $20^{\circ} \mathrm{C}$, (5) $15^{\circ} \mathrm{C}$, (6) $10^{\circ} \mathrm{C},(7) 5^{\circ} \mathrm{C}$

$\mathrm{pH}: 4.3$, Wavelength : $536 \mathrm{~m} \mu$

て分解が完了することを知り，アミノプロピロンの分解 条件を $35(\mathrm{v} / \mathrm{v}) \%$ 㧧酸で 3 時間加熱還流することに した.

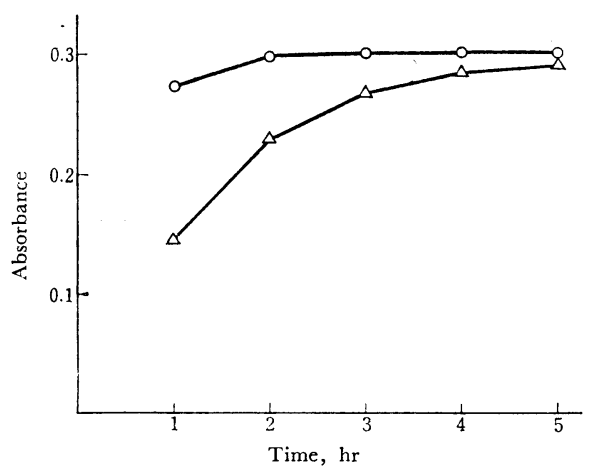

Fig. 4 Hydrolizing condition of aminopropylon $\mathrm{pH}: 4.3$, Wavelength : $536 \mathrm{~m} \mu$ ○ $35 \%$ Sulfuric acid $\triangle 20 \%$ Sulfuric acid

\section{5 検量線および測定精度}

3 に準じて分解，中和したのち，アミノブロピロン浱 度 $100 \sim 700 \mu \mathrm{g} / \mathrm{ml}$ の水溶液空調製し, その各 $1 \mathrm{ml}$ に 䣷酸塩䌅衝液（pH 4.3) $10 \mathrm{ml}$ を加え,ついで $1.0(\mathrm{w} /$ v) \% ニンヒドリン溶液 $5 \mathrm{ml}$ を加え, さらに酭酸塩緩

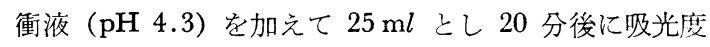
を測定した (Fig.6). その結果, 本発色反応牥アるノプ ロピロン濃度 $4 \sim 28 \mu \mathrm{g} / \mathrm{m} l$ の範囲内で, アミノプロピ ロン量に対するニンヒドリン量の相対的変化の影響は認 


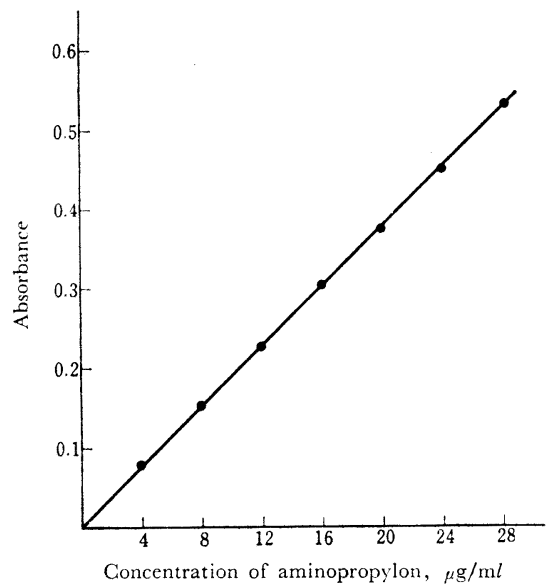

Fig. 5 Calibration curve $\mathrm{pH}: 4.3$, Wavelength $: 536 \mathrm{~m} \mu$

められず，ベールの法則を满足した。

最小自乗法によって作製した検量式（アミノプロピロ ン $\mu \mathrm{g} / \mathrm{m} l=53.82 \times$ 吸光度-0.209) を游， 3 に準じ て分解，中和し， $200 \mathrm{ml}$ (アミ)プロピロン濃度 : 400 $\mu \mathrm{g} / \mathrm{m} l)$ とした㳸 $1 \mathrm{ml}$ についてくりかえし発色操作を 行ない測定した測定精度（標準誤差）は, 室温（約 $25^{\circ} \mathrm{C}$ ) に扎て $\sigma^{\prime}=0.272 \%(n=6)$ であった（Table I).

Table I Analytical results of aminopropylon

\begin{tabular}{ccccc}
\hline \hline$n$ & $\begin{array}{c}\text { Aminopropylon } \\
(\mathrm{mg})\end{array}$ & $\begin{array}{c}\text { Absorbance } \\
(\mathrm{mg})\end{array}$ & $\begin{array}{c}\text { Found } \\
(\mathrm{mg})\end{array}$ & $\begin{array}{c}\text { Recovery } \\
(\%)\end{array}$ \\
\hline 1 & 82.35 & 0.307 & 81.57 & 98.05 \\
2 & 81.06 & 0.306 & 81.30 & 100.30 \\
3 & 80.30 & 0.300 & 79.69 & 99.24 \\
4 & 78.98 & 0.296 & 78.61 & 99.53 \\
5 & 81.71 & 0.307 & 81.57 & 99.83 \\
6 & 82.79 & 0.314 & 83.46 & 100.81 \\
& & & & 99.793 \\
Mean & & & & 0.272 \\
\hline \multirow{2}{*}{ Standard error } & & & \\
\hline
\end{tabular}

$\dagger$ Calculated by the calibration formula.

\section{5 共存成分の影響}

鎮痛薬，感冒薬としてしばしば配合される医薬品と しては，フェナセチン，アミノピリン，塩酸エフェドリ ン，スルピリン，硫酸キニーネ，ブロムワレリル尿素な ぞがあげられるが，アミノプロピロン $40 \mathrm{mg}$ にこれら 医薬品（39 種）適量を配合し，35(v/v) \% 硫酸 $5 \mathrm{ml}$ を用い，3に準じて分解，中和した液を $100 \mathrm{ml}$ （アミ ノプロピロン濃度 : $400 \mu \mathrm{g} / \mathrm{ml}$ ) とし, その $1 \mathrm{ml}$ につ
き発色操作を行ない吸光度を測定, 検量式により定量し た結果，配合医薬品の大部分は定量を妨害せず，フェナ セチン, アセトアミノフェン, 塩酸ノスカピン, スルピ リン, アスコルビン酸, クェン酸, 糖類, 硝酸チアミン が障害となったが，いずれも簡単な前処理によってこれ らの影響を除去しえた（Table II）。

\section{$5 \cdot 1$ フェナセチンの除去法}

フェナセチンは硫酸で加熱分解後中和するとき淡黄〜 かっ色に着色，さらにニンヒドリンによってきわめてわ ずかに紅色を呈するため多少プラス誤差を伴う。アミ， プロピロンおよびフェナセチンの混合物を分液漏斗中に とり，1\% 塩酸 $20 \mathrm{ml}$ 执よびエーテル $30 \mathrm{ml}$ を加えて 振り混ぜるとき，アミノプロピロンは塩酸層にフフェナ セチンはエーテル層に移行するが，塩酸層をふたたびエ 一テル $30 \mathrm{~m} l$ で洗浄, エーテル層は水 $2 \mathrm{~m} l$ および $1 \mathrm{~m} l$ でくりかえし洗浄したのち洗液を先の塩酸層に移し，40 $(\mathrm{w} / \mathrm{v}) \%$ 水酸化ナトリウム溶液 $2 \mathrm{~m} l$ 叴加え，ク口ロ ホルムまたは食塩飽和下にベンゼンを用いて $20 \mathrm{~m} l$ ずつ 4 回アミノプロピロンを抽出する.

\section{$5 \cdot 2$ 塩酸ノスカピンの除去法}

塩酸ノスカピンは硫酸で加熱分解するとき淡かっ色〜 濃かっ色に着色し，中和寸るとき带緑かっ色に変色寸る が，ニンヒドリン反応を执さえるためか多少マイナス誤 差を伴う・アミノプロピロンおよび塧酸ノスカピンを水 $10 \mathrm{~m} l$ に溶かし, 希塩酸を滴加して生起したノスカピン を溶解させたのち, $1 N$ 酢酸ナトリウム液約 $5 \mathrm{ml}$ を滴加 し，しばらく放置後生ずる沈殿をガラスフィルターを用 いてろ過し,水 $1 \mathrm{~m} l$ ずつで数回よく洗浄したのち，ろ液 (約 $20 \mathrm{ml}$ ) に $40(\mathrm{w} / \mathrm{v}) \%$ 水酸化ナトリウム溶液 $1 \mathrm{ml}$ を加え，クロロホルムまたは食塩飽和下にベンゼンを用 いて $20 \mathrm{ml}$ ずつ 4 回アミノプロピロンを抽出する。

\section{$5 \cdot 3$ その他妨害成分の除去法}

アセトアそノフェンはフェナセチンと同様に多少プラ ス誤差在伴う・スルピリン，硝酸チアミン，リン酸りボ フラビンはマイナス誤差，また糖類および有機酸類は硫 酸と加熱するとき炭化しマイナス誤差を伴う。これらは いずれも混合物に $10(\mathrm{w} / \mathrm{v}) \%$ 水酸化ナトリウム溶液 $10 \sim 30 \mathrm{ml}$ を加光て溶かしたのち，等量のクロロホルム または食塩飽和下にベンゼンを用いて 4 回アミノプロピ ロンを抽出する. $5 \cdot 1 ， 5 \cdot 2 ， 5 \cdot 3$ については続報で報告 する。 
報 文 小泉，世一，竹本：ニンヒドリンによる混合製剤中のアミノプロピロン比色定量法の検討

Table II Analytical results of aminopropylon in mixed pharmaceutical preparations

\begin{tabular}{|c|c|c|c|c|c|c|}
\hline \multirow{2}{*}{ No. } & \multicolumn{3}{|c|}{ Component } & \multirow{2}{*}{ Absorbance } & \multirow{2}{*}{ Found $\dagger(\mathrm{mg})$} & \multirow{2}{*}{ Recovery (\%) } \\
\hline & Others (mg) & & Aminopropylon (mg) & & & \\
\hline 1 & Aminopyrine & 100 & 41.77 & 0.315 & 41.86 & 100.22 \\
\hline 2 & Antipyrine & 300 & 41.24 & 0.305 & 40.52 & 98.24 \\
\hline 3 & Isopropylantipyrine & 100 & 39.49 & 0.299 & 39.71 & 100.55 \\
\hline 4 & Sulpyrine & 300 & 40.04 & 0.296 & 39.31 & $98.16+\dagger$ \\
\hline 5 & Pyrabital & 300 & 39.46 & 0.297 & 39.44 & 99.95 \\
\hline 6 & Barbital & 300 & 40.27 & 0.303 & 40.25 & 99.95 \\
\hline 7 & Bromovalerylurea & 500 & 40.05 & 0.295 & 39.17 & 97.80 \\
\hline 8 & Bromodiethylacetylurea & 300 & 40.74 & 0.302 & 40.11 & 98.46 \\
\hline 9 & Caffein & 200 & 42.04 & 0.316 & 42.00 & 99.89 \\
\hline 10 & Plokon & 5 & 41.04 & 0.305 & 40.52 & 98.72 \\
\hline 11 & Methiphemin & 50 & 39.54 & 0.296 & 39.31 & 99.41 \\
\hline 12 & Methiphemin $\mathrm{H}$ & 30 & 40.42 & 0.301 & 39.98 & 98.91 \\
\hline 13 & Ephedrine hydrochloride & 25 & 41.97 & $0.312^{\circ}$ & 41.46 & 98.78 \\
\hline 14 & Methyl ephedrine hydrochloride & 30 & 40.45 & 0.300 & 39.84 & 98.50 \\
\hline 15 & Chlorphenylamine maleate & 100 & 40.69 & 0.300 & $39: 84$ & 97.91 \\
\hline 16 & Diphenhydramine hydrochloride & 50 & 41.39 & 0.314 & 41.73 & 100.81 \\
\hline 17 & Qunine sulfate & 200 & 40.75 & 0.306 & 40.65 & 99.75 \\
\hline 18 & Acetylsalicylic acid & 500 & 41.92 & 0.315 & 41.86 & 99.86 \\
\hline 19 & Aluminum acetyl salicylate & 200 & 41.27 & 0.305 & 40.52 & 98.18 \\
\hline 20 & Salicylamide & 1000 & 42.73 & 0.318 & 42.27 & 98.91 \\
\hline 21 & Phenacetin & 300 & 40.98 & 0.303 & 40.25 & $98.22+\dagger$ \\
\hline 22 & Acetaminophenol & 200 & 41.26 & 0.307 & 40.79 & $98.85+\dagger$ \\
\hline 23 & Noscapine hydrochloride & 40 & 40.73 & 0.301 & 39.98 & $98.16+t$ \\
\hline 24 & Nicotinamide & 200 & 42.21 & 0.318 & 42.27 & 100.14 \\
\hline 25 & Thiamine nitrate & 20 & 40.84 & 0.305 & 40.52 & $99.22 \dagger \dagger$ \\
\hline 26 & Acetanilide & 100 & 40.90 & 0.301 & 39.98 & 97.75 \\
\hline 27 & Taurine & 100 & 41.18 & 0.312 & 41.46 & 100.68 \\
\hline 28 & Ethoxybenzamide & 100 & 40.21 & 0.296 & 39.31 & 97.76 \\
\hline 29 & Ascorbic acid & 500 & 40.50 & 0.304 & 40.38 & $99.70+\dagger$ \\
\hline 30 & Citric acid & 500 & 43.05 & 0.318 & 42.27 & $98.19+\dagger$ \\
\hline 31 & Sorbit & 18 & 40.72 & 0.302 & 40.11 & 98.50 \\
\hline 32 & $p$-oxy-benzoyl-ethyl ester & 10 & 38.96 & 0.292 & 38.77 & 99.50 \\
\hline 33 & $p$-oxy-benzoyl-butyl ester & 10 & 38.96 & 0.292 & 38.77 & 99.50 \\
\hline 34 & Sodium cyclamate & 10 & 39.95 & 0.298 & 39.57 & 99.06 \\
\hline 35 & Saccharine sodium & 10 & 41.36 & 0.306 & 40.65 & 98.28 \\
\hline 36 & Glucose & 500 & 43.05 & 0.318 & 42.27 & $98.19+\dagger$ \\
\hline 37 & Sucrose & 500 & 43.05 & 0.318 & 42.27 & $98.19+\dagger$ \\
\hline 38 & Lactose & 500 & 43.05 & 0.318 & 42.27 & $98.19+\dagger$ \\
\hline 39 & Riboflavine phosphate & 10 & 43.05 & 0.318 & 42.27 & $98.19+\dagger$ \\
\hline
\end{tabular}

$\dagger$ Calculated by the calibration formula. $+\dagger$ Treated with pre-separate procedure

\section{6 絈語}

以上，アミノプロピロンを $35(\mathrm{v} / \mathrm{v}) \%$ 硫酸で 3 時間

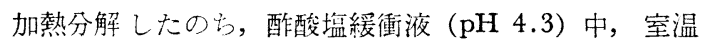
に扎いてニンヒドリンと反応させ, 検量線によって比色 定量する方法は, きわ好精度よく, またア々ノプロピ ロンとしばしば配合される医薬品の影響も少なく定量す ることができじゅうぶえ満足できる結果を得たが，われ われは，アミノプロピロン酸分解物のニンヒドリン反応 が反応温度によって若干影響されることを考虑し, 定量 にあたってはそのつど標準品（融点：186ª）について 同様操作した発色液と比色し定量する方法をとった。
終わりに，本研究にあたり種々ご助言を賜わった京都 大学薬学部教授宇野豊三博士に深謝します.

本研究の機会を与えられた日本新薬株式会社森下 弘 社長に謹謝します。また，終始で助言を賜わった日本新 薬株式会社開発室室長里田 勲博士ならびに開発試験部 高田正夫部長に深謝します。

\section{交献}

1) S. Ruhemann : J. Chem. Soc., 1911, 792, 1486.

2) 山岸正治 : 本誌, 4, 584 (1955).

$$
\text { ¿̀ }
$$

The scrutinization of colorimetric determination of aminopropylon with ninhydrin in mixed pharmaceutical preparations. (Analysis of amino- 
propylon. I.) Junji KoIzumi, Yoshitaka Yorchi and Teisaburo TAкемото (Analytical Division, Institute of Chemical Research, Nippon Shinyaku Co., Ltd., Minami-ku, Kyoto)

The authors presented a specific method for colorimetric assay of aminopropylon. The hydrolyzate of aminopropylon forms a soluble reddish-violet pigment with ninhydrin in acidic aqueous solution even at room temperature. The pigment in solution has two absorption peaks at $414 \sim 416 \mathrm{~m} \mu$ and at $536 \mathrm{~m} \mu$, respectively.

The peak at $536 \mathrm{~m} \mu$ is not influenced by reagent blank absorption, so that it is used as an assay wavelength. Aminopropylon existing with other compounds such as ephedrine-hydrochloride, sulupyrin (J.P.), and quinine-sulfate can be determined with good accuracy.

(Received Jan. 28, 1966)

\title{
ニンヒドリンによるアミノプロピロンの比色定量における 配合成分の影響*
}

\author{
小泉 淳二, 世一 義隆, 上野 政一**
}

\begin{abstract}
アミノプロピロンを硫酸で加水分解したのちニンヒドリンと反応させ比色定量する方法を前報りで報 告した．今回は, 解熱鎮痛剤, 抗ヒスタミン剂, 鎮がい剂などと混合しているアミノプロピロンに本法 を適用したとき，妨害劣る成分の有無，扎よびその除去方法について検討した。 その絬果，前報で記し たノスカピン，フェナセチンのほ加，p-アセトアミノフェノール，ニコチノイル-4-アミノアンチピリ ンが本法を妨害し，また，アセチルサリチル酸なども妨害する打それがあった。しかし，試料を塩酸酸 性溶液としク口ロホルムで抽出すると, ニコチノイル-4-アミノアンチピリン以外の妨害成分は, ほと んどクロロホルム㟄に移りアミノプロピロンは塩酸酸性水風に残るため分離することができた。この処 理法により妨害成分を除去し，ニンヒドリン法を適用するとアミノプロピロンは精度よく定量するとと ができる。
\end{abstract}

\section{1 緒言}

アミノプロピロンは解熱鎮痛薬として広く使用され， 感冒薬製剂にもよく配合されている・しかし，製刜中の 分離定量法としては，いままで適応範囲の広い適当な力 法が見いだされなかった。著者らは前報において，ア ミノプロピロンを硫酸で加水分解した生成物にニンヒド リンを作用させるとき紅紫色に呈色することを見いだ し，この呈色反応はじゅうぶん定量に利用できることを 報告したまた，アミノプロピロンと配合を子想される 各種成分について，本定量法への妨害の有無をあわせ検 討した。

本報で著者らはさらに検討範再を広げ解熱鎮痛薬, 鎮 静薬, 抗ヒスタミン薬, 鎮がい薬, および気管支拡張薬 などについて示された Table III の各成分, および最

*アミノプロピロンの分析研究（第 2 報）

** 日本新薬株式会社開発試験部分析課：京都市南区西 大路八条下ル
大配伍量を参考とし，前報で未検討のものをおもに取り 上げ本定量法への影響を検討するとともに，前報で検討 不じゅうぶんであった定量妨害成分の分離法をさらに検 討した。

アミノプロピロンと, 前報で妨害成分として指摘した ノスカピン，フェナセチンの混合物に $0.1 N$ 塩酸を加え クロロホルムと振り混ぜて抽出するとき, アミノプロピ ロンは $0.1 N$ 塩酸層に溶存し, ノスカピン, フェナセチ ンはクロロホルム層に溶存して分離することができた。 さらに Table III の各成分についても本定量法中で硫 酸による加水分解中で析出物を生ずる成分，あるいは着 色する成分があるが，ほとえどはクロロホルム層に転溶 しアミノプロピロンと分離することができる．この前処 理操作を併用して本定量法を適用することにより，適用 範囲の広いアミノプロピロンの定量法を確立することが できた・

ただ，ニコチノイル-4-アえノアンチピリンはこの前 処理操作でアミノプロピンと分離することができず，本 